\title{
MOWING INTENSITY INFLUENCES DEGREE OF CHANGES IN CARABID BEETLE ASSEMBLAGES
}

\author{
SCHWERK, A. - DYMITRYSZYN, I. \\ Laboratory of Evaluation and Assessment of Natural Resources, \\ Warsaw University of Life Sciences - SGGW \\ Nowoursynowska Street 166, 02-787 Warsaw, Poland \\ (phone: +48-22-59-32189; fax: +48-22-59-32227) \\ *Corresponding author \\ e-mail: aschwerk@yahoo.de \\ (Received 24 $4^{\text {th }}$ Apr 2017; accepted $5^{\text {th }}$ Jul 2017)
}

\begin{abstract}
Mowing measures are frequently used as a tool for species conservation. However, mowing intensity as well as ecological characteristics of different sites may have an influence on the respective species or assemblages. Based on a BACI study design we tested if the effect of mowing on carabid assemblages is more pronounced with a higher intensity of the mowing measures, and if the results are influenced by differences in environmental characteristics between individual study sites. Based on 2650 carabid individuals belonging to 43 species we demonstrated that an intensification of mowing intensity resulted in an increased effect on the carabid coenoses. While assemblages from study sites mown once in the year were located closer to those from unmown sites, assemblages from study sites mown twice in the year were clearly separated in ordination analysis. However, some environmental variables, as shown by plant indicator values, accounted for a comparatively high amount of the variance. The study confirms that in the context of using mowing as a measure for nature conservation the mowing intensity has to be taken into account, but also variation in environmental factors.
\end{abstract}

Keywords: Carabidae, post agricultural land, mowing measures, biological diversity, BACI

\section{Introduction}

Since long man has influenced his surrounding nature and environment. For example, with cutting of woodland in the middle ages agricultural landscapes became dominant in Europe. Changes in agricultural practices in the recent past lead to intensification of agriculture and change in land use, which are assessed to be main drivers of loss in biological diversity (e.g. Matson et al., 1997; Watt et al., 2007; Haźi et al., 2012). Thus, retransformation of agricultural production in order to contribute to ecosystem integrity is a key challenge of the twenty-first century (Scherr and McNeely, 2008). According to Gonthier et al. (2014) conservation strategies in agriculture require a multi-scale approach including reducing local management intensity and landscapelevel approaches incorporating natural or semi-natural areas.

Traditional agricultural practices, as mowing in order to produce hay, should receive special attention. Mowing has also been proposed as a surrogate for grazing (Morris, 2000). Yet, diversity patterns depend on management intensity. For example, Kitahara et al. (2000) observed a highly significant decrease in butterfly species numbers with increasing mowing intensity. Likewise, Marini et al. (2000) detected reduced orthopteran and butterfly diversity with high fertilisation and cutting frequency. Carabid beetles are known to react to management practices in grassland habitats as well (Rainio and Niemelä, 2003) and are sensitive to human-altered abiotic conditions (Koivula, 2011). For example, regarding mowing of Swiss montane meadows Grandchamp et al. (2005) demonstrated a positive influence of fertilization intensity on species richness. 
Number of cuts was positively related to the number of individuals. Mown sites in the central-eastern Alps had significantly more species than natural grasslands (Gobbi et al., 2015). Carabid beetles play an important role in agricultural systems, for example as biological control agents on agricultural pests (Humphreys and Mowat, 1994) or seed predators of weeds (Saska, 2008; Petit et al., 2014).

In 2013 a study was started following a "before-after-control-impact" (BACI) study design in order to analyse the effect of mowing measures on carabid beetles. A rather low management intensity in the second year of study (one-time mowing in the first week of July 2014) resulted in a rather weak effect of the mowing measures (Schwerk and Kitka, 2016). Hence, it remained an open question, if an intensification the mowing measures will lead to a more pronounced effect on the carabid assemblages. Moreover, differences in site characteristics independent from the mowing measures might have an additional influence on the formation of the carabid coenoses. Therefore, we increased the mowing intensity from one-time mowing to mowing twice in a third year of the study. In addition, we conducted phytosociological surveys on the study sites in order to specify site characteristics not related to the mowing measures.

The aim of the presented paper was to test (1) if the effect of mowing on carabid assemblages is more pronounced with a higher intensity of the mowing measures, and (2) if the results are influenced by differences in environmental characteristics between individual study sites.

\section{Material and methods}

\section{Study sites and field methods}

The study was carried out in 2013-2015 on post-agricultural fallow land abandoned from crop production for 21 years in 2013, located in the research area "Krzywda" in Western Poland (Dymitryszyn et al., 2013). Todays' relief of the region is connected to the last phase of the Baltic glaciation with sand and loams covering almost the whole area. It is located in the zone of Atlantic climate with western wind dominating and a yearly rainfall of about 500-600 mm (Kucharski and Pawlaczyk, 1997; UMiG Tuczno, 2001). According to Matuszkiewicz et al. (1995) "Krzywda" is situated in the range of continental mesotrophic oak-pine mixed forest (Pino-Quercetum).

The study followed a "before-after-control-impact" (BACI) design with three treatment sites and three control sites. Thus, six study sites (B1 - B6) of $50 \mathrm{~m} \times 50 \mathrm{~m}$ were established, three of which (B1, B4, B5) were mown with biomass removal on July, 5, in 2014 and on June, 26-27, and August, 17-18, in 2015. The remaining three study sites (B2, B3, B6) were left untreated in 2014 and 2015 (Figure 1).

Carabids were collected as described by Schwerk (2014a) using pitfall traps (Barber, 1931) from mid-May to mid-September. Three pitfall traps (distance $3 \mathrm{~m}$ ) were installed in the center of each study site. The location of the traps was the same in each year of the study. Traps were glass jars topped with a funnel (upper diameter of about $10 \mathrm{~cm}$ ) set flush with the soil surface. A roof was suspended a few $\mathrm{cm}$ above the funnel and ethylene glycol was used as a killing agent and preservative. In order to guarantee their proper functioning the traps were regularly controlled (about every two weeks). Determination and nomenclature of the individuals collected was carried out according to Freude et al. (2004).

At each study site an area of $6 \mathrm{~m} \times 6 \mathrm{~m}$ was marked in order to elaborate a phytosociological survey. The surveys were elaborated in the second week of June 2015 
(before the first mowing on the treatment sites) by recording the species and describing their occurrence using the cover-abundance scale of Braun-Blanquet (1964).
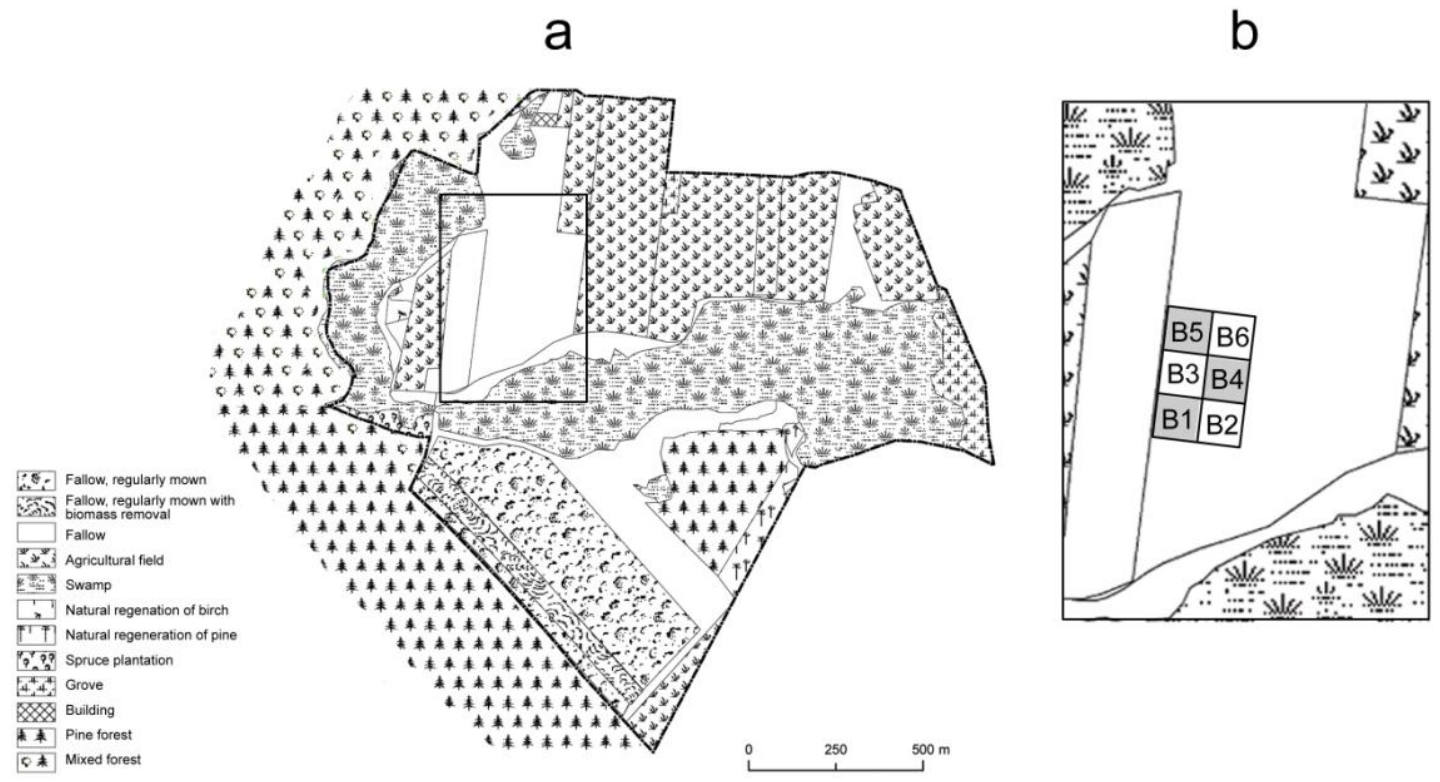

Figure 1. Scheme of the research area "Krzywda" (a) with the location of study sites B1-B6 (b). Study sites mown in 2014 and 2015 are indicated by grey colour (from Schwerk and Kitka, 2016)

\section{Statistical methods}

The results of the three traps were pooled to one sample for each study site. For each species, the total number of individuals per study site and the dominance value (percentage share of the individuals of the respective species on the total number of individuals collected at the study site) were calculated.

For each phytosociological survey the values of coverage of the plant species were transformed to a value of mean percentage cover according to Braun-Blanquet (1964): + $-0.1 \%, 1-5 \%, 2-17,5 \%, 3-37,5 \%, 4-62,5 \%$, and 5-87,5\% (Appendix 1). Next, for each study site ecological indicator values of vascular plants were calculated according to Zarzycki et al. (2002). The ecological values according to Zarzycki are a modification of the method of ecological values of vascular plants according to Ellenberg (1974) adapted to the conditions of the Polish climate. Ecological indicator values for light, temperature, soil moisture, trophy (fertility), soil acidity $(\mathrm{pH})$, soil granulometric composition, and organic matter content (humus) were calculated for each study site as a weighted average value of particular plant species cover values.

In order to analyse the similarities between the carabid coenoses a hierarchical cluster analysis was carried out using PAST v. 2.17c (Hammer et al., 2001; Hammer, 2012), with Euclidian distance as distance measure and agglomeration according to Ward. The dominance values of the species at the respective study sites were used. The strength of the nodes was tested by bootstrapping analysis (1999 resamplings). Bootstrap proportions (percentage of replicates where the node is still supported) of $\geq 70 \%$ correspond to a probability of $\geq 95 \%$ that the respective clade is correct (Hillis and Bull, 1993). 
We carried out gradient analyses using the CANOCO for Windows version 4.53 (ter Braak, 1987; ter Braak and Šmilauer, 2002) with the aim to obtain information about the environmental basis determining the major pattern in variation (ter Braak and Prentice, 1988). DCA was first used to select the appropriate statistical model based on the longest gradient (ter Braak and Prentice, 1988) and then principal components analysis (PCA) was carried out. PCA was done using inter-sample distances without post-transformation of species scores. Because dominance values were used, the data were not transformed. CanoDraw for Windows version 4.14 was used to create a biplot with species fit range adjusted in such a manner that the 10 species with the highest fit into the ordination space were displayed (ter Braak and Šmilauer, 2002).

In order to test the significance of the individual environmental variables and the mowing treatment (defined as nominal variable) in 2015, we carried out a redundancy analysis (RDA) with Monte Carlo permutation tests (unrestricted, 1999 permutations) first for each variable separately and then using automatic forward selection of variables (reduced model) using CANOCO for Windows version 4.53 (ter Braak and Šmilauer, 2002).

\section{Results}

During the three years of study 2650 carabid individuals belonging to 43 species were collected. Total numbers of collected individuals declined constantly during the study, whereas total numbers of species increased from 2013 to 2014 but dropped from 2014 to 2015. A decline in numbers of species and individuals in 2015 is particularly evident for the control sites (Appendix 2).

The calculated plant indicator values exposed differences between the individual study sites (Table 1). High results for all indicator values were detected on study site B2, whereas study sites B5 and B6 exhibited comparatively low results for the majority of the indicator values. Thus, the values indicated a slight north-south gradient with respect to the site characteristics. Moreover, it is striking that the results for light values are particularly high on the control sites.

Table 1. Plant indicator values recorded for the study sites in 2015 (L, light; T, temperature; $M$, moisture; Tr, trophy; A, acidity; GC, granulometric composition; H, humus)

\begin{tabular}{lccccccc}
\hline Study site / site type & L & T & M & Tr & A & GC & H \\
\hline B1 / Treatment site & 3.92 & 3.65 & 3.02 & 3.43 & 3.90 & 3.92 & 2.00 \\
\hline B2 / Control site & 5.23 & 4.38 & 3.10 & 3.55 & 4.78 & 4.38 & 2.33 \\
\hline B3 / Control site & 4.47 & 3.61 & 2.44 & 2.79 & 3.79 & 3.47 & 1.97 \\
\hline B4 / Treatment site & 4.20 & 3.64 & 2.86 & 3.45 & 3.98 & 3.63 & 1.95 \\
\hline B5 / Treatment site & 4.70 & 3.52 & 2.11 & 2.32 & 3.47 & 3.14 & 2.00 \\
\hline B6 / Control site & 4.99 & 3.50 & 2.01 & 2.01 & 3.50 & 3.01 & 2.00 \\
\hline
\end{tabular}

The cluster analysis separated the carabid coenoses into two basic clusters, strongly supported by a bootstrapping proportion of $100 \%$ (Figure 2). The first cluster contained all samples of study sites mown twice in 2015, two samples of study sites, which were mown once in 2014 (B4, B5) and the sample of the control site B6 from 2015. This cluster was divided into two clusters (bootstrapping proportion of $24 \%$ ), resulting in a separation of study sites B1 and B4 from 2015 (two times mown) from the remaining 
sites. The second basic cluster contained all remaining samples from not mown sites (i.e. all remaining samples from control sites and the samples from B1, B4 and B5 from 2013) and also the sample from study site B1 from 2014, which was mown one time. Within this cluster the samples from study B6 of the years 2013 and 2014 were separated from the remaining samples (bootstrapping proportion of 15\%).

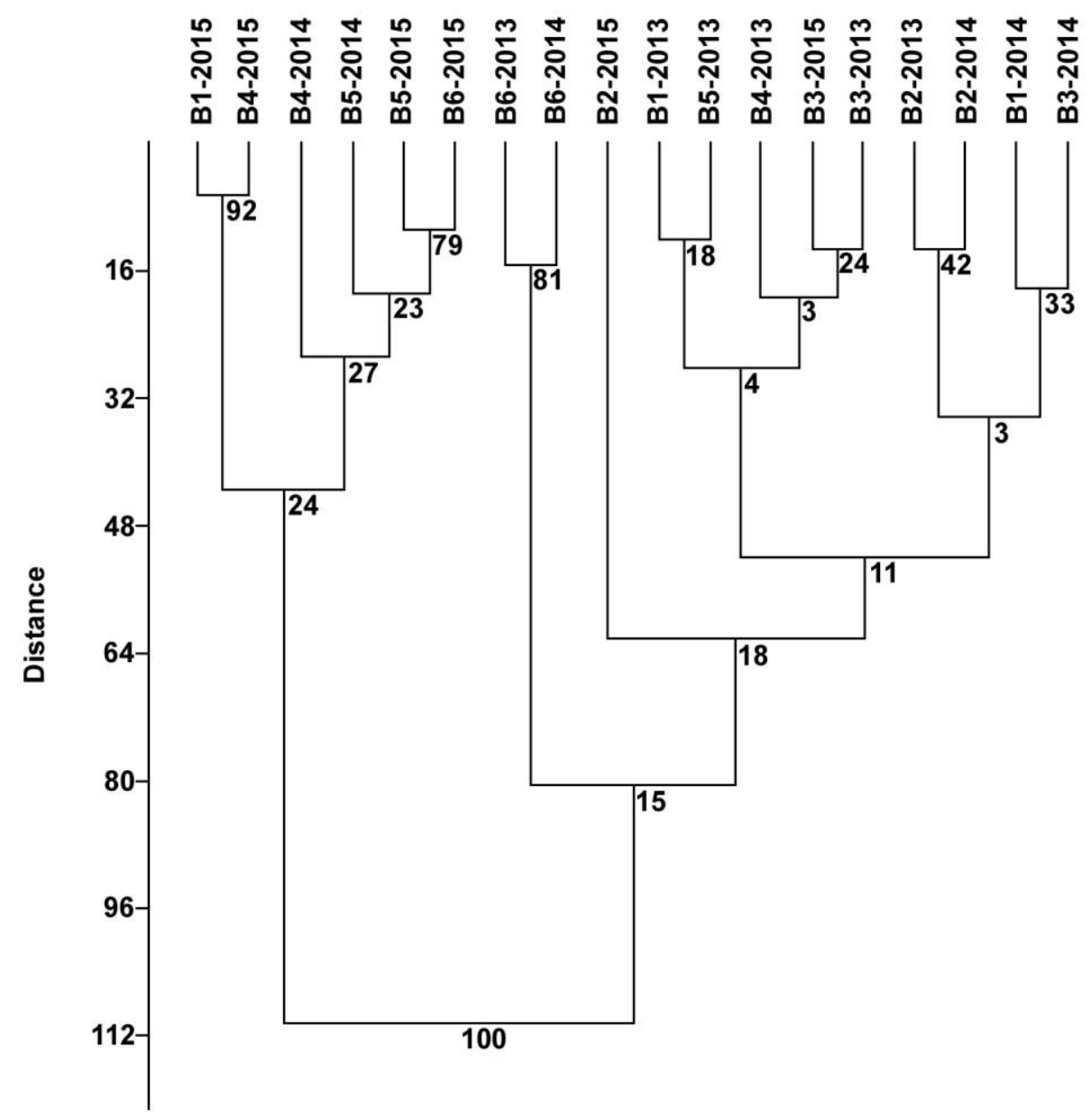

Figure 2. Cluster analysis of the results based on Euclidian distance as distance measure and agglomeration according to Ward. Numbers indicate the percentage of replicates where each node is still supported (Hammer, 2012)

The first and second ordination axis of the PCA (Figure 3) explained $39.4 \%$ and $22.7 \%$ of the variation in the dataset respectively. The study sites showed a distribution along the first ordination axis with respect to management intensity. Study sites two times mown in 2015 were located the most to the right side of the diagram. Two of the study sites being mown once in 2014 (B4, B5) were also somewhat shifted to the right side. However, the sample of study site B1 from 2014 (also mown one time) was located on the left side together with the majority of unmown sites, i.e. samples from treatment sites of the year 2013 and control sites. All three samples on study site B6 are located most on the upper site of the diagram along the second ordination axis. The sample of the year 2015 of this study site is also shifted quite far to the right side of the 
diagram. Among the species Calathus fuscipes was related to samples from study sites which were two times mown, whereas Calathus erratus took an intermediate position between samples from study sites two times mown and study site B6. Amara aenea was related to study site B6. Species related to samples from unmown study sites were Harpalus luteicornis, Poecilus versicolor, and Pterostichus niger.

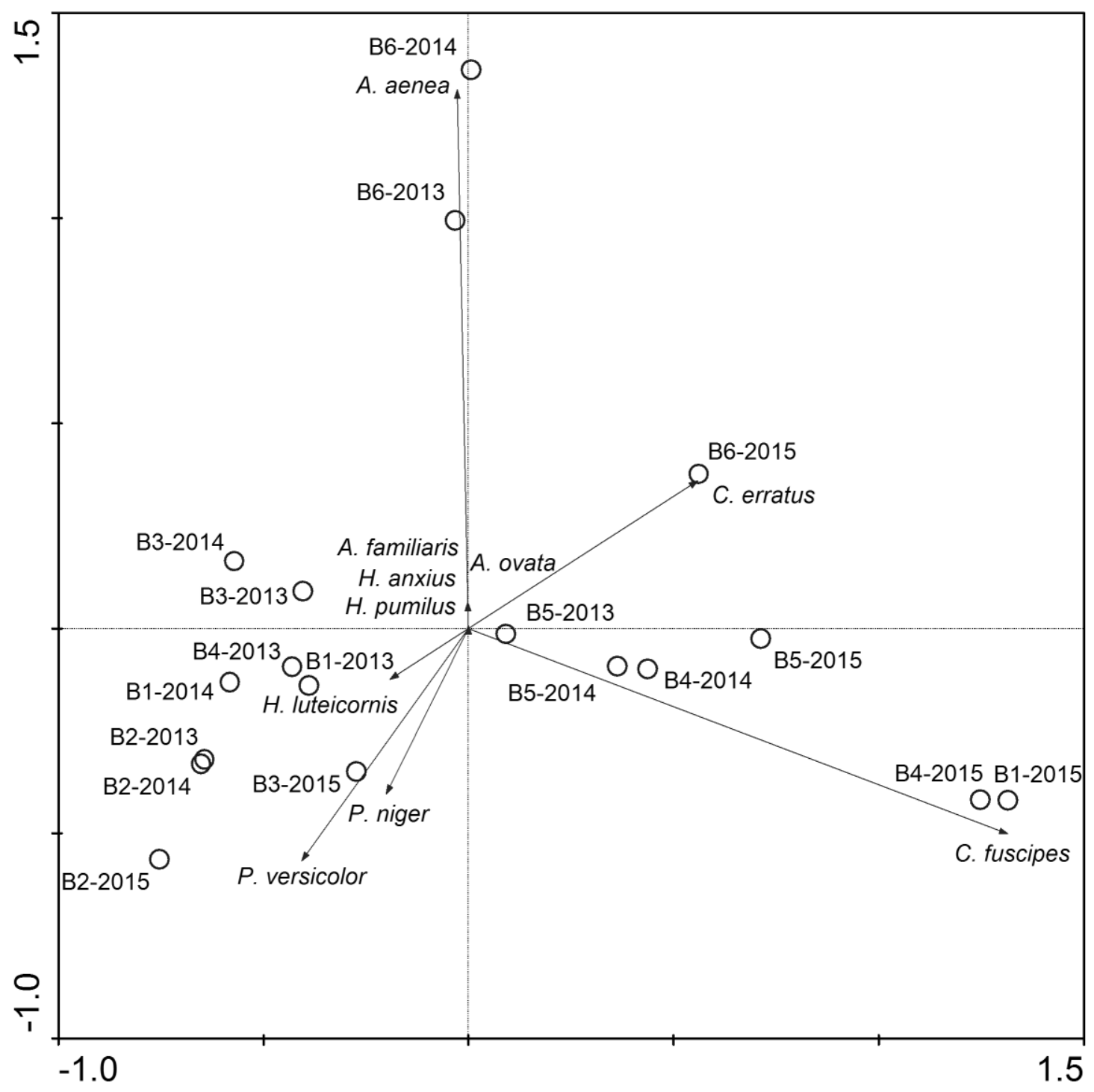

Figure 3. Ordination plot based on principal components analysis (PCA) of the results for study sites (open circles) and species (arrows)

Testing the environmental variables separately using Monte Carlo permutation tests revealed highest Lambda-1 values (above 40\%) for humus content, temperature, light, and mowing (not mowing respectively), i.e. these variables accounted for most of the variance when considered singly (Table 2). However, none of them was statistically significant. When using forward selection Lambda-A values (additional variance the variable explained at the time it was included in the model) for temperature, light and the mowing measures are considerably reduced compared to the Lambda- 1 values. 


\section{Discussion}

Our results indicated that the management intensification from one-time mowing (in 2014) to mowing twice (in 2015) indeed resulted in an increased effect on the carabid coenoses. The cluster analysis resulted in a strong supported separation of almost all mown sites from the unmown sites and a weaker separation of two of the sites mown twice from the sites mown only once. However, the increased effect is particularly visible in the position of the carabid samples along the first ordination axis in the PCA. In Welsh peatland strong grazing by cattle and horses resulted in a strong influence on carabid assembages compared to an only little influence due to light sheep grazing (Holmes et al., 1993). Kaltsas et al. (2013), who investigated the response of carabid beetles to grazing in Cretan shrublands, described carabids as good indicators of grazing pressure at assemblage level, rather than species-specifically. Overgrazing resulted in lower species richness, and species richness and diversity were maximal under moderate to relatively high levels of grazing. Similarly, in a study by Mayr et al. (2007) carabid beetle diversity was the highest in grasslands with medium management intensity. In the study by Grandchamp et al. (2005) the number of cuts was positively related to the number of individuals. Since in our study a decline in numbers of species and individuals was visible particularly on the control sites, it seems that mowing at least counteracted trends of declining species and individual numbers.

Table 2. Results of Monte Carlo permutation tests of the environmental variables tested separately and using automatic forward selection of variables (reduced model). During forward selection of variables "Temperature", "Light", "Unmown", and "Trophy" were not added to the model due to collinearity. Lambda-1 - variance explained by the environmental variables separately; Lambda-A - additional variance explained when included in the model using forward selection

\begin{tabular}{lcccccc}
\hline \multirow{2}{*}{ Variable } & \multicolumn{3}{c}{ Tested separately } & \multicolumn{4}{c}{ Forward selection } \\
\cline { 2 - 7 } & Lambda-1 & $\mathbf{F}$ & $\boldsymbol{p}$ & Lambda-A & $\mathbf{F}$ & $\boldsymbol{p}$ \\
\hline Humus & 0.47 & 3.56 & 0.111 & 0.47 & 3.56 & 0.111 \\
\hline Temperature & 0.46 & 3.42 & 0.109 & - & - & - \\
\hline Light & 0.44 & 3.16 & 0.058 & - & - & - \\
\hline Mown & 0.44 & 3.13 & 0.099 & 0.02 & 0.00 & 1.000 \\
\hline Unmown & 0.44 & 3.13 & 0.104 & - & - & - \\
\hline pH & 0.39 & 2.55 & 0.117 & 0.12 & 5.71 & 0.176 \\
\hline Gran. comp. & 0.29 & 1.67 & 0.218 & 0.15 & 2.17 & 0.243 \\
\hline Moisture & 0.22 & 1.12 & 0.372 & 0.24 & 2.41 & 0.108 \\
\hline Trophy & 0.22 & 1.12 & 0.363 & - & - & - \\
\hline
\end{tabular}

Among the carabid beetle species Calathus fuscipes showed the most distinct connection to the mowing treatment. Calathus erratus also benefitted from the mowing measures, but was also regularly frequent on study site B6. This result is in accordance with Schwerk and Szyszko (2009) and Schwerk (2014b), who detected highest abundances of these species on regularly mown fallow grounds. Calathus fuscipes seems to be particularly sensitive to management intensity, since it also showed higher numbers of individuals in agricultural fields subjected to conventional tillage with ploughing compared to fields with non-inversion tillage (Kosewska et al., 2014). The special position of study site B6 in the ordination diagram as well as the grouping of B6 from 2015 with the treatment sites in the cluster analysis points to special environmental 
characteristics specific for this study site. This aspect is supported by the differences in site characteristics revealed by the indicator values elaborated for 2015 . The conclusion is possible that Calathus erratus reacts also on some characteristic not related to mowing. Accordingly, despite in average highest abundances on the treatment sites in 2014 (one time mown), Schwerk and Kitka (2016) could not demonstrate a statistically significant reaction of Calathus erratus on mowing. Harpalus luteicornis, Pterostichus niger, and Poecilus versicolor were closer related to not mown study sites. Former studies had already shown that Poecilus versicolor reacts much less on mowing measures than Calathus fuscipes and Calathus erratus (Schwerk and Szyszko, 2009; Schwerk, 2014b). Pterostichus niger is known as species preferring forest habitats, but was also detected regularly in different field margins (Asteraki et al., 1995). This species reacted significantly on a management intensity of one-time mowing on the study sites (Schwerk and Kitka, 2016).

A significant meaning has to be attributed also to differences in environmental characteristics between the sites, as for example the special position of study site B6 in the ordination diagram indicates. Several of the variables seem to be largely replaceable by each other, as indicated by the reduced Lambda-1 values when using forward selection. In our study particularly organic content (humus) accounted for a high amount of the variance in the assemblages. The significance of this parameter has been already described in literature. Gardner et al. (1997), studying the consequences of grazing pressure on carabids on heather moorlands in northeast Scotland, detected a strong influenced of soil organic content. In Welsh peatland biotopes the nutrient status and saturation of the substrate were most important with respect to carabid assemblages (Holmes et al., 1993). Sądej et al. (2012) showed a positive relation between soil organic matter and carabid species number in experimental agricultural fields in northern Poland.

According to Digweed et al. (1995) distances of $50 \mathrm{~m}$ should provide adequate statistical independence between traps. Yet, it cannot be excluded that the one-time mowing in 2014 on the treatment sites contributed to some degree to the more pronounced differences on these sites in 2015. However, since the effect of the mowing measures in 2014 was quite weak, we assess an influence on the results in 2015 as rather insignificant. It is reasonable to assume that the observed differences in 2015 were caused by the increased mowing intensity causing a more continuous effect on the carabids due to an earlier first mowing compared to 2014 and the additional later second mowing, which may have provoked some species to conduct linear direct walking behaviour in order to escape from unfavorable habitats (e.g. Baars, 1979; Riecken and Raths, 1996) and other species to enter the treatment sites.

Our study confirms that in the context of using mowing as a measure for nature conservation the mowing intensity has to be taken into account, since it appears that certain species can be facilitated by modifying mowing intensity. Additionally, the impact of environmental factors and their spatial variation has to be considered. In this regard attention should be paid to soil organic content. However, time of mowing is of importance too, for example delayed mowing may have a different effect on individual species or taxonomic groups (e.g. Humbert et al., 2012).

Acknowledgements. The authors like to thank Karsten Hannig for confirming the identification of some beetles and four anonymous referees for valuable comments on a former version of the manuscript. This paper is communication No. 485 of the Laboratory of Evaluation and Assessment of Natural Resources, Warsaw University of Life Sciences - SGGW. 


\section{REFERENCES}

[1] Asteraki, E. J., Hanks, C. B., Clements, R. O. (1995): The influence of different types of grassland field margin on carabid beetle (Coleoptera, Carabidae) communities. Agriculture, Ecosystems and Environment 54: 195-202.

[2] Baars, M. A. (1979): Patterns of movement of radioactive carabid beetles. - Oecologia (Berl.) 44: 125-140.

[3] Barber, H.S. (1931): Traps for cave inhabiting insects. - Journal of the Elisha Mitchell Scientific Society 46: 259-266.

[4] Braun-Blanquet, J. (1964): Pflanzensoziologie; Grundzüge der Vegetationskunde. Springer-Verlag, Wien, New York

[5] Digweed, S. C., Currie, C. R., Carcamo, H. A., Spence, J. R. (1995): Digging out the "digging-in effect" of pitfalltraps: Influences of depletion and disturbance on catches of ground beetles (Coleoptera: Carabidae). - Pedobiologia 39: 561-576.

[6] Dymitryszyn, I., Szyszko, J., Rylke, J. (eds) (2013): Field methods of evaluation and assessment of natural resources. Wydawnictwo SGGW, Warsaw

[7] Ellenberg, H. (1974): Zeigerwerte der Gefäßpflanzen Mitteleuropas. Scripta Geobotanica IX, E. Goltze, Göttingen

[8] Freude, H., Harde, K.-W., Lohse, G.A., Klausnitzer, B. (2004): Die Käfer Mitteleuropas. Bd. 2, Adephaga 1, Carabidae (Laufkäfer). 2. (erweiterte) Aufl., Spektrum, Heidelberg/Berlin

[9] Gardner, S. M., Hartley, S. E., Davies, A., Palmer, S. C. F. (1997): Carabid communities on heather moorlands in northeast Scotland: the consequences of grazing pressure for community diversity. - Biological Conservation 81: 275-286.

[10] Gobbi, M., Fontaneto, D., Bragalanti, N., Pedrotti, L., Lencioni, V. (2015): Carabid beetle (Coleoptera: Carabidae) richness and functional traits in relation to differently managed grasslands in the Alps. - Annales de la Société entomologique de France (N.S.) 51: 5259.

[11] Gonthier, D. J., Ennis, K. K., Farinas, S., Hsieh, H.-Y., Iverson, A. L., Batáry, P., Rudolphi, J., Tscharntke, T., Cardinale, B. J., Perfecto, I. (2014): Biodiversity conservation in agriculture requires a multi-scale approach. - Proceedings of the Royal Society B 281: 20141358.

[12] Grandchamp, A.-C., Bergamini, A., Stofer, S., Niemelä, J., Duelli, P.,Scheidegger, C. (2005): The influence of grassland management on ground beetles (Carabidae, Coleoptera) in Swiss montane meadows. - Agriculture, Ecosystems and Environment 110: 307-317.

[13] Hammer, Ø. (2012): PAST. PAleontological STatistics. Version 2.17. Reference manual. Natural History Museum, University of Oslo

[14] Hammer, Ø., Harperd, A. T., Ryan, P. D. (2001): PAST: Paleontological statistics software package for education and data analysis. - Palaeontologia Electronica 4: 1-9.

[15] Házi, J., Penksza, K., Bartha, S., Hufnagel, L., Tóth, A., Gyuricza, Cs., Szentes, Sz. (2012): Cut mowing and grazing effects with grey cattle on plant species composition in case of pannon wet grasslands. - Applied Ecology and Environmental Research 10: 223231.

[16] Hillis, D. M., Bull, J. J. (1993): An empirical test of bootstrapping as a method for assessing confidence in phylogenetic analysis. - Systematic Biology 42: 182-192.

[17] Holmes, P. R., Boyce, D. C., Reed, D. K. (1993): The ground beetle (Coleoptera: Carabidae) fauna of welsh peatland biotopes: factors influencing the distribution of ground beetles and conservation implications. - Biological Conservation 63: 153-161.

[18] Humbert, J.-Y., Pellet, J., Buri, P., Arlettaz, R. (2012): Does delaying the first mowing date benefit biodiversity in meadowland? - Environmental Evidence 1: 9. 
[19] Humphreys, I. C., Mowat, D. J. (1994): Effects of some organic treatments on predators (Coleoptera: Carabidae) of Cabbage Root Fly, Delia radicum (L.) (Diptera: Anthomyiidae), and on alternative prey species. - Pedobiologia 38: 513-518.

[20] Kaltsas, D., Trichas, A., Kougioumoutzis, K., Chatzaki, M. (2013): Ground beetles respond to grazing at assemblage level, rather than species-specifically: the case of Cretan shrublands. - Journal of Insect Conservation 17: 681-697.

[21] Kitahara, M., Sei, K., Fujii, K. (2000): Patterns in the structure of grassland butterfly communities along a gradient of human disturbance: further analysis based on the generalist/specialist concept. - Population Ecology 42: 135-144.

[22] Koivula, M. J. (2011): Useful model organisms, indicators, or both? Ground beetles (Coleoptera, Carabidae) reflecting environmental conditions. - ZooKeys 100: 287-317.

[23] Kosewska, A., Skalski, T., Nietupski, M. (2014): Effect of conventional and noninversion tillage systems on the abundance and some life history traits of carabid beetles (Coleoptera: Carabidae) in winter triticale fields. - European Journal of Entomology 111: 669-676.

[24] Kucharski, B., Pawlaczyk, P. (1997): Drawieński Park Narodowy i okolice. Wyd. PTTK „Kraj”, Warszawa

[25] Marini, L., Fontana, P., Battisti, A., Gaston, K. J. (2009): Agricultural management, vegetation traits and landscape drive orthopteran and butterfly diversity in a grasslandforest mosaic: a multi-scale approach. Insect Conservation and Diversity 2: 213-220.

[26] Matson, P. A., Parton, W. J., Power, A. G., Swift, M. J. (1997): Agricultural intensification and ecosystem properties. - Science 277: 504-509.

[27] Matuszkiewicz, W., Faliński J.B., Kostrowicki A.S., Matuszkiewicz J.M., Olaczek R., Wojterski T., 1995, Potencjalna roślinność naturalna Polski. Mapa przeglądowa 1:300000. Arkusze 1-12, IGiPZ PAN, Warszawa

[28] Mayr, S., Wolters, V., Dauber, J. (2007): Ground beetles (Coleoptera: Carabidae) in anthropogenic grasslands in Germany: effects of management, habitat and landscape on diversity and community composition. - Wiadomości entomologiczne 26: 169-184.

[29] Morris, M. G. (2000): The effects of structure and its dynamics on the ecology and conservation of arthropods in British grasslands. - Biological Conservation 95: 129-142.

[30] Petit, S., Boursault, A., Bohan, D. A. (2014): Weedseed choice by carabid beetles (Coleoptera: Carabidae): Linking field measurements with laboratory diet assessments. European Journal of Entomology 111: 615-620.

[31] Rainio, J., Niemelä, J. (2003): Ground beetles (Coleoptera: Carabidae) as bioindicators. Biodiversity and Conservation 12: 487-506.

[32] Riecken, U., Raths, U. (1996): Use of radio telemetry for studying dispersal and habiat use of Carabus coriaceus L. - Annales Zoologici Fennici 33: 109-116.

[33] Saska, P. (2008): Composition of weed community determines carabid assemblage. - In: Penev L, Erwin T, Assmann T (Eds.) Back to the roots and back to the future. Towards a new synthesis between taxonomic, ecological and biogeographical approaches in Carabidology. Pensoft Publishers, Sofia, Moscow, p 339-351.

[34] Sądej, W., Kosewska, A., Sądej, W., Nietupski, M. (2012): Effects of fertilizer and landuse type on soil properties and ground beetle communities. - Bulletin of Insectology 65: 239-246.

[35] Scherr, S. J., McNeely, J. A. (2008): Biodiversity conservation and agricultural sustainability: towards a new paradigm of 'ecoagriculture' landscapes. - Philosophical Transactions of the Royal Society B 363: 477-494.

[36] Schwerk, A. (2014a): Changes in carabid beetle fauna (Coleoptera: Carabidae) along successional gradients in post-industrial areas in Central Poland. - European Journal of Entomology 111: 677-685.

[37] Schwerk, A. (2014b): Distribution and spatial autocorrelation of carabid species in differently treated post-agricultural areas. - Baltic Journal of Coleopterology 14: 141150 . 
[38] Schwerk, A., Kitka, M. A. (2016): Influence of mowing measures on carabid beetle fauna (Coleoptera: Carabidae) in a post-agricultural area. - Periodicum Biologorum 118: 163169.

[39] Schwerk, A., Szyszko, J. (2009): Distribution and spatial preferences of carabid species (Coleoptera: Carabidae) in a forest-field landscape in Poland. - Baltic Journal of Coleopterology 9: 5-15.

[40] ter Braak, C. J. F. (1987): CANOCO - A FORTRAN Program for Canonical Community Ordination by (partial) (detrended) (canonical) Correspondence Analysis, Principal Components Analysis and Redundancy Analysis (version 2.1). DLO-Agricultural Mathematics Group, Wageningen

[41] ter Braak, C. J. F, Prentice, I. C. (1988): A theory of gradient analysis - Advances in Ecological Research 18: 271-317.

[42] ter Braak, C. J. F., Šmilauer, P. (2002): CANOCO Reference Manual and CanoDraw for Windows User's Guide: Software for Canonical Community Ordination (version 4.5). Microcomputer Power, Ithaca

[43] UMiG Tuczno (2001): Tuczno. Wyd. BUR Media, Bydgoszcz

[44] Watt, A. D., Bradshaw, R. H. W., Young, J., Alard, D., Bolger, T., Chamberlain, D., Fernández-González, F., Fuller, P., Gurrea, P., Henle, K., Johnson, R., Korsós, Z., Lavelle, P., Niemelä, J., Nowicki, P., Rebane, M., Scheidegger, C., Sousa, J. P., van Swaay, C., Vanbergen, A. (2007): Trends in biodiversity in Europe and the Impact of land-use change. - Issues in Environmental Science and Technology 25: 135-160.

[45] Zarzycki, K., Trzcińska-Tacik, H., Różański, W., Szeląg, Z., Wołek, J., Korzeniak, U. (2002): Ecological values of vascular plants of Poland. Ekologiczne liczby wskaźnikowe roślin naczyniowych Polski. - In: Mirek, Z. (Ed.) Biodiversity of Poland. Różnorodność biologiczna Polski, Vol. 2. Instytut Botaniki im. W. Szafera, Kraków, p 1-183. 


\section{APPENDIX}

Appendix 1. Mean percentage cover according to Braun-Blanquet (1964) of the recorded species on the study sites in 2015

\begin{tabular}{|c|c|c|c|c|c|c|}
\hline Species & 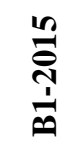 & 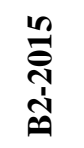 & $\begin{array}{l}\text { ñ } \\
\text { ஸे } \\
\text { ஸ் }\end{array}$ & 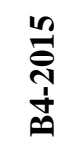 & 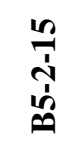 & 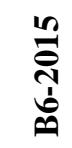 \\
\hline \multicolumn{7}{|c|}{ Herbaceous layer } \\
\hline Achillea millefolium $\mathrm{L}$. & & 5.0 & 5.0 & 5.0 & & \\
\hline Agrostis capillaris L. & 5.0 & 5.0 & & 17.5 & 17.5 & \\
\hline Anthemis arvensis L. & 0.1 & & & & & \\
\hline Anthoxanthum odoratum L. & & & & 5.0 & 0.1 & 0.1 \\
\hline Armeria elongata (Hoffm.) W. D. J. Koch & & & 0.1 & & 0.1 & \\
\hline Arrhenatherum elatius (L.) P. Beauv. & 37.5 & 17.5 & 17.5 & 17.5 & 0.1 & 0.1 \\
\hline Artemisia campestris L. & & 0.1 & & & & 0.1 \\
\hline Artemisia vulgaris $\mathrm{L}$. & 0.1 & 5.0 & 0.1 & 0.1 & & \\
\hline Bromus sp. & & & & 0.1 & & \\
\hline Calamagrostis epigejos Roth. & & & & & 0.1 & \\
\hline Cardaminopsis arenosa (L.) Hayek & 0.1 & 0.1 & & 0.1 & & \\
\hline Carlina vulgaris $\mathrm{L}$. & 0.1 & & & & & \\
\hline Cerastium holosteoides Fr. em. Hyl. & 0.1 & & 0.1 & & 0.1 & \\
\hline Dactylis glomerata $\mathrm{L}$. & 0,1 & & & & & \\
\hline Daucus carota $\mathrm{L}$. & 5.0 & & & 5.0 & & \\
\hline Deschampsia caespitosa (L.) P. Beauv. & 5.0 & & & 0.1 & & \\
\hline Deschampsia flexuosa (L.) Trin. & 5.0 & 17.5 & & 5.0 & 0.1 & 0.1 \\
\hline Dianthus deltoides L. & & & 0.1 & & 5.0 & \\
\hline Festuca ovina L. & & 17.5 & 5.0 & & & 0.1 \\
\hline Galium mollugo L. & 0.1 & & 5.0 & 5.0 & & \\
\hline Galium verum $\mathrm{L}$. & 5.0 & 17.5 & 0.1 & 17.5 & 0.1 & \\
\hline Gnaphalium sylvaticum L. & 0.1 & & & & & \\
\hline Helichrysum arenarium (L.) Moench & 0.1 & & 0.1 & & & 0.1 \\
\hline Hieracium laevigatum Willd. & 0.1 & & & & & \\
\hline Hieracium pilosella $\mathrm{L}$. & 0.1 & 5.0 & 37.5 & 0.1 & 62.5 & 87.5 \\
\hline Holcus lanatus L. & 5,0 & & & 17.5 & 0.1 & \\
\hline Hypochoeris radicata $\mathrm{L}$. & & & & & 0.1 & \\
\hline Leontodon autumnalis L. & & & & 0.1 & & 0.1 \\
\hline Phleum pratense L. & & & 0.1 & 5.0 & & \\
\hline Pimpinella saxifraga L. & & & 0.1 & & 0.1 & \\
\hline Pinus sylvestris L. & & & & & & 0.1 \\
\hline Polygonum amphibium L. & & & 0.1 & & & \\
\hline Potentilla argentea $\mathrm{L}$. & 0.1 & 0.1 & & & & \\
\hline Rumex thyrsiflorus Fingerh. & & 0.1 & 0.1 & & 0.1 & \\
\hline Scleranthus annuus L. & & & & & 0.1 & \\
\hline Senecio jacobaea L. & 0.1 & & 0.1 & 0.1 & & \\
\hline Tragopogon pratensis L. & & & & 0.1 & & \\
\hline Veronica officinalis L. & 17.5 & & 5.0 & & & \\
\hline Vicia angustifolia $\mathrm{L}$. & 0.1 & & 0.1 & 0.1 & & \\
\hline Vicia hirsuta (L.) S. F. Gray & 5.0 & & 0.1 & & & 0.1 \\
\hline Vicia villosa Roth. & 0.1 & & 5.0 & 0.1 & & \\
\hline Viola arvensis Murray & 0.1 & 0.1 & 0.1 & & & \\
\hline \multicolumn{7}{|c|}{ Moss layer } \\
\hline Polytrichum juniperinum Hedw. & & & 5.0 & & 0.1 & 5.0 \\
\hline Pleurozium schreberi (Willd.) Mitten. & 5.0 & 5.0 & & & & \\
\hline
\end{tabular}


Appendix 2. Numbers of individuals of the recorded species on the study sites in 2013, 2014 and 2015

\begin{tabular}{|c|c|c|c|c|c|c|c|c|c|c|c|c|c|c|c|c|c|c|}
\hline Species & 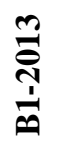 & 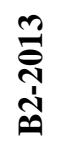 & 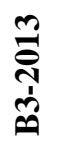 & $\begin{array}{l}\stackrel{m}{\bar{乛}} \\
\stackrel{7}{*}\end{array}$ & 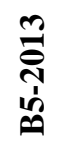 & 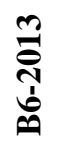 & 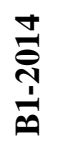 & 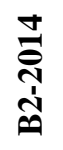 & 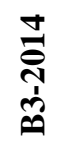 & 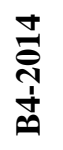 & 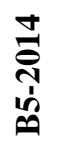 & 离 & $\underset{n}{\stackrel{n}{\grave{8}}}$ & 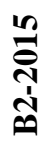 & 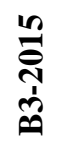 & 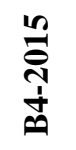 & 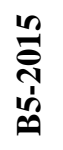 & 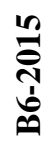 \\
\hline Agonum gracilipes (Duftschmid, 1812) & & & 1 & & & & & & & & & & & & & & & \\
\hline Amara aenea (De Geer, 1774) & 1 & 1 & 8 & & 6 & 21 & & 2 & 9 & & 4 & 110 & & & & & 2 & 7 \\
\hline Amara bifrons (Gyllenhal, 1810) & & & & & & & & 1 & & & 1 & 6 & & & & & & \\
\hline Amara communis (Panzer, 1797) & & 1 & 1 & 2 & 1 & 1 & & 2 & 1 & 1 & 16 & 18 & & & & & & 3 \\
\hline Amara convexior Stephens, 1828 & 6 & 12 & 23 & 19 & 5 & & 34 & 11 & 16 & 7 & 5 & 11 & & 2 & 3 & 9 & 4 & \\
\hline Amara curta Dejean, 1828 & & & & 1 & & & & & & & & & & & & & & \\
\hline Amara familiaris (Duftschmid, 1812) & 1 & & & & & 1 & & & & & & 6 & & & & & & \\
\hline Amara lunicollis Schiödte, 1837 & 11 & 8 & 2 & 16 & 2 & 2 & 19 & 19 & 2 & & 3 & & 1 & 1 & & 1 & & \\
\hline Amara ovata (Fabricius, 1792) & & & & & & & & & & & & 1 & & & & & & \\
\hline Amara plebeja (Gyllenhal, 1810) & 2 & 4 & & 3 & & 1 & 3 & 3 & & & 2 & & 1 & & & & & \\
\hline Amara spreta Dejean, 1831 & & & & & & & & 1 & & & & & & & & & & \\
\hline Amara tibialis (Paykull, 1798) & & & & & & & & & & & & 3 & & & & 1 & 1 & \\
\hline Anisodactylus nemorivagus (Duftschmid, 1812) & & & & & & & 1 & & & & & & & & & & & \\
\hline Calathus cinctus Motschulsky, 1850 & & & & & & & & & & & & & & & & & 3 & \\
\hline Calathus erratus (C. R. Sahlberg, 1827) & 11 & 1 & 9 & 18 & 17 & 14 & 7 & 1 & 1 & 35 & 12 & 37 & 15 & & & 38 & 19 & 13 \\
\hline Calathus fuscipes (Goeze, 1777) & 1 & & 5 & 2 & 17 & 1 & & 2 & & 25 & 28 & 10 & 40 & & 4 & 112 & 27 & 12 \\
\hline Calathus melanocephalus (Linné, 1758) & 10 & 4 & 4 & 5 & 1 & 5 & 2 & 5 & & & 4 & 9 & 2 & 3 & & 13 & 12 & 12 \\
\hline Carabus granulatus Linné, 1758 & & & & & 1 & & & & & & 1 & & & & & & & \\
\hline Cychrus caraboides (Linné, 1758) & & & & & & & & 1 & & & & & & & & & & \\
\hline Cymindis angularis Gyllenhal, 1810 & & 1 & 1 & & 1 & & & & & & & 2 & & & & & & \\
\hline Harpalus affinis (Schrank, 1781) & & & & & & & & & & & 1 & & & & 1 & & & 1 \\
\hline Harpalus anxius (Duftschmid, 1812) & & & & & & & & & & & & 1 & & & & & & \\
\hline Harpalus griseus (Panzer, 1796) & & & & & & 2 & & & & & & & & & & & & \\
\hline Harpalus latus (Linné, 1758) & 4 & 4 & & 11 & 2 & & 4 & & 5 & 9 & 2 & 1 & & & 1 & 15 & & \\
\hline Harpalus luteicornis (Duftschmid, 1812) & 1 & 15 & 3 & 8 & 3 & 2 & 5 & 12 & 8 & 10 & 1 & & & 6 & 2 & 3 & & 2 \\
\hline Harpalus pumilus Sturm, 1818 & & & & & & & & & & & & 1 & & & & & & \\
\hline Harpalus rubripes (Duftschmid, 1812) & 30 & 18 & 34 & 28 & 26 & 14 & 21 & 13 & 5 & 4 & 10 & 17 & 6 & 8 & 7 & 9 & 7 & 6 \\
\hline Harpalus rufipalpis Sturm, 1818 & & 1 & & & & & & & & & & & & & & & & \\
\hline Harpalus rufipes (De Geer, 1774) & 41 & 42 & 25 & 49 & 30 & 12 & 15 & 9 & 7 & 25 & 30 & 24 & 9 & 8 & 8 & 22 & 30 & 16 \\
\hline
\end{tabular}




\begin{tabular}{|c|c|c|c|c|c|c|c|c|c|c|c|c|c|c|c|c|c|c|}
\hline Harpalus signaticornis (Duftschmid, 1812) & & & & & & & & & & & & & \multicolumn{6}{|c|}{1} \\
\hline Harpalus smaragdinus (Duftschmid, 1812) & 2 & & & & & & & & & & & & & & & & & \\
\hline Harpalus tardus (Panzer, 1796) & 12 & 61 & 19 & 49 & 3 & 3 & 6 & 31 & 7 & 21 & 8 & 18 & 2 & 6 & 5 & 7 & & 2 \\
\hline Panagaeus bipustulatus (Fabricius, 1775) & & & & & & & 1 & & 1 & & & & & & & & & \\
\hline Poecilus cupreus (Linné, 1758) & 1 & & & & & & & & & & & & & & & & 1 & \\
\hline Poecilus lepidus (Leske, 1785) & 1 & 1 & & 1 & 3 & 1 & & & & & 1 & & & & 1 & & 4 & 1 \\
\hline Poecilus versicolor (Sturm, 1824) & 23 & 12 & 8 & 7 & 10 & 1 & 15 & 19 & 2 & 6 & 6 & 3 & 4 & 28 & 4 & 10 & 2 & \\
\hline Pterostichus melanarius (Illiger, 1798) & 6 & & 2 & 3 & 12 & 1 & 1 & 1 & & & 5 & & 3 & 1 & & 1 & & \\
\hline Pterostichus niger (Schaller, 1783) & 17 & 46 & 5 & 13 & 15 & & 5 & 25 & 12 & 4 & 11 & & 7 & 4 & 5 & 19 & 5 & \\
\hline Pterostichus oblongopunctatus (Fabricius, 1787) & 1 & & 1 & & 1 & & & & & & & & & & & & & \\
\hline Syntomus truncatellus (Linné, 1761) & & & & & & & 1 & & & & & & & & & & 1 & \\
\hline Synuchus vivalis (Illiger, 1798) & & & & & 2 & & 1 & & & & 2 & & & & & & 2 & \\
\hline Trechus obtusus Erichson, 1837 & & & & & & & & & & & & & & & & & 1 & \\
\hline Zabrus tenebrioides (Goeze, 1777) & & & & & 2 & & & & & & & & & & & & & \\
\hline Individuals & 182 & 232 & 151 & 235 & 160 & 82 & 141 & 158 & 76 & 147 & 153 & 278 & 90 & 68 & 41 & 260 & 121 & 75 \\
\hline Species & 20 & 17 & 17 & 17 & 21 & 16 & 17 & 18 & 13 & 11 & 21 & 18 & 11 & 11 & 11 & 14 & 16 & 11 \\
\hline Individuals (total for the year) & & & & & & & & & & 53 & & & & & & 55 & & \\
\hline Species (total for the year) & & & & & & & & & & 2 & & & & & & 25 & & \\
\hline
\end{tabular}

